\title{
Antimicrobial Susceptibility of Euphorbia tirucalli Extracts and the Effect of Latex on Growth and Viability of Mouse Breast Cancer Cells EMT-6
}

\author{
Khalil Lafi Aljabarin, M. Farraj, Bahjat Jabarin, and Zhou Jian Feng \\ Department of Internal Medicine, Tongji hospital, Medical College, Huazhong University of Science and \\ Technology, Wuhan, China \\ Department of Immunology and Microbiology, Medical Science college, Birzeit University, Palestine
}

\begin{abstract}
Summary: Euphorbia tirucalli is a plant presents in many countries which also known as Aveloz. This tree used in traditional medicine for treatment different types of disease. In this research we tested the effects of aveloz latex, stem and leaves extracts on different gram positive and gram negative bacteria, and its effects on some types of fungi, also we tested the aveloz effects on mouse breast cancer cells. So we did extraction for leaves and stems of aveloz by methanol and prepared the latex directly from the tree by aseptic technique. Then we prepared different dilutions from the 3 products, then we prepared the inoculums, culture and sensitivity techniques were be performed, tissue culture for mouse breast cancer cells and latex were performed to study its anti-cancer effects. Results showed us there were effects of the stem and leaves extracts on some types of bacteria where the latex appeared a best sensitivity on some fungi species. There was an interesting effect of latex on cancer cells. Aveloz products can be used in producing materials to prepare medical products may be help in treating different diseases.
\end{abstract}

Key words: Euphorbiaceae; Euphorbia tirucali; Aveloz; Latex; EBV (Epestein bar Virus); CFU-GM (colony forming unit- Granulocyte Monocyte)

\section{Introduction}

Euphorbia tirucalli, a garden plant from Africa, belongs to the family Euphorbiaceae. Other names used include Tirucalia indica, Tithymalus tirucalli, and Euphorbia viminalis. Common names used to for this plant include pencil tree, aveloz. All parts of the tree secrete a white milky fluid referred to as latex (1). The latex of Aveloz contains terpenes including phorbol esters and ingenol esters which cause severe irritation upon direct exposure. It contains fatty acid fractions consist of palmitic and linoleic acids, phytosterol consist of sitosterol, stigmasterol, campesterol and cholesterol, and also contain cyanidin glycoside (2). The latex, stem and leaves of Aveloz tree are used in traditional medicine in many countries to treat several diseases, particularly skin diseases (3).

Therefore, we were tested the stem, leaves extracts and latex, on several multidrug resistant microorganisms. Several gram positive and gram negative bacteria, yeasts and molds were obtained and cultured. Facultative gram positive cocci such as Staphylococcus aureus, Staphylococcus epidermides, micrococcus lutens, vancomycin resistance enterococcus, enterococcus faecalis, and MRSA. Gram negative bacteria such as Pseudomonas aeruginosa, E. coli, K. pneumoniae Proteus mirabilis, Shigella Sonni, Shigella flaxiniri, Pseudomonas MDR, and Actinobacter MDR. Fungi which include Candida sp, Aspergillus spp, Fuzarium, and Rhizopus. Antimicrobial susceptibility was performed following the recommendations of CLSI. In addition, the anti tumor properties of the latex were tested in-vitro on the breast cancer cells EMT-6 cells.

\subsection{Aveloz}

\section{Materials and Methods}

Aveloz latex was collected following aseptic techniques directly from the euphorbia tree in a sterile tube. The latex was then placed in a cooler and transferred immediately to the laboratory for proper storage and testing. Aveloz was also extracted from the plant's stem and leaves separately: Pieces from the stem and leaves were individually mixed in a blender and the homogenate was placed in a flask with $200 \mathrm{ml}$ methanol for 24 hours. The liquid was then filtered through several layers of sterile gauze and then centrifuged at 5000xg for 15 minutes. The supernatant was then carefully removed and placed in a white glass plate to evaporate the alcohol. The remaining fluid was then collected and placed in a sterile tube to be tested.

\subsection{Microorganisms}

ATCC strains of Gram positive, gram negative bacteria and fungus were obtained from the stocks at the laboratory of the Master's Program at Birzeit University. The antimicrobial and anti fungal characteristics of 
the aveloz latex, leaves and stem extracts were evaluated on Mueller-Hinton agar following the recommendations of CLSI. The optimal dilution was determined by applying several dilutions of the aveloz to filter paper disks placed on the surface of agar plates seeded with the organism to be tested.

\subsection{Effects of Aveloz Latex on Mouse Breast Cancer Cells TEM-6}

The mouse breast cancer cells EMT- 6 were seeded in 24 wells plates. A total of $1 \times 10^{4}$ cells were seeded in each well and the plate was incubated for 24 hours. The medium was then removed, the cells washed with HBSS and the aveloz latex was applied in triplicate at different dilutions. RPMI-1640 medium supplemented with $10 \%$ FBS was added to three wells and used as positive control. After 48 hours of incubation, the medium from each well was removed and placed in $15 \mathrm{ml}$ conical centrifuge tube. Trypsin EDTA was added to each well $(200 \mathrm{ul})$ and the plate was incubated at $37^{\circ} \mathrm{C}$ for 5 minutes. RPMI-1640 was then added to each well (200 ul) to stop the action of the trypsin and the contents of each well were placed in the respective conical centrifuge tube. After centrifugation for 7 minutes at $700 \mathrm{xg}$, the supernatant was removed and the cells were suspended in $500 \mathrm{ul}$ of RPMI-1640 medium. Total and viability counts were then performed and recorded. The distribution of the different aveloz latex dilutions in the 24 well plates as well as the positive control wells is shown in (Table 1).

\begin{tabular}{|c|r|r|r|r|r|r|}
\hline \multirow{2}{*}{ Tube } & \multicolumn{7}{|c|}{ Tubes numbers } \\
\cline { 2 - 7 } & $\mathbf{1}$ & $\mathbf{2}$ & $\mathbf{3}$ & $\mathbf{4}$ & $\mathbf{5}$ & $\mathbf{6}$ \\
\hline $\mathbf{A}$ & $10^{-1}$ & $10^{-2}$ & $10^{-3}$ & $10^{-4}$ & $10^{-5}$ & $10^{-6}$ \\
\hline $\mathbf{B}$ & $10^{-1}$ & $10^{-2}$ & $10^{-3}$ & $10^{-4}$ & $10^{-5}$ & $10^{-6}$ \\
\hline $\mathbf{C}$ & $10^{-1}$ & $10^{-2}$ & $10^{-3}$ & $10^{-4}$ & $10^{-5}$ & $10^{-6}$ \\
\hline D & $\begin{array}{c}\mathrm{c} \\
\text { control }\end{array}$ & $\begin{array}{c}\mathrm{c} \\
\text { control }\end{array}$ & $\begin{array}{c}\mathrm{c} \\
\text { control }\end{array}$ & $\begin{array}{c}\mathrm{co} \\
\text { control }\end{array}$ & $\begin{array}{c}\mathrm{c} \\
\text { control }\end{array}$ & control \\
\hline
\end{tabular}

Table 1. Distribution of the aveloz latex dilutions in the wells and the positive control wells.

\subsubsection{Counting of Cells and Estimation of Viability}

The cells (200 ul) were mixed with HBSS (300 ul) and trypan blue stain (500 ul). The tube was briefly vortexed and allowed to stand at room temperature for 5 minutes. A hemocytometer chamber was then properly filled with the stained cells. Four corner squares were then counted. The total number of cells was calculated according to the following formula:

Total number of cells $=$ Average number $/$ square $\mathrm{X}$ dilution factor $\mathrm{X} 10^{4}$

Viability was determined according to the following formula:

Viability $=\underline{\text { Total number of cells }- \text { blue or dead cells }}$

Total number of cell

\subsection{Inoculums Preparations}

The bacteria was inoculated on blood agar plates and incubated for 18 to 24 hours, while fungus was inoculated on Sabaraud Dextrose agar until growth occurs on room temperature. One or two colonies were then removed and a suspension equivalent to 0.5 MacFarland was prepared. A sterile cotton swab was then dipped in the suspension, the excess fluid removed by gently rotating the swab against the inside of the tube containing the suspension. The swab was then used to inoculate the surface of Mueller-Hinton agar plates. Sterile filter paper discs were then aseptically placed on the surface of the agar plates and $5 \mathrm{ul}$ of each aveloz dilution was placed in duplicate to the filter paper. The plates were incubated for 18 to 24 hours in a non-CO2 incubator; the zone diameters were accurately measured using Vernier caliper and recorded.

Several strains of ATCC strains of Gram positive and negative bacteria were used including: Gram -ve bacteria: Proteus mirabilis, Shigella Sonni, shigella flaxiniri, E. coli, Pseudomonas MDR, Pseudomonas earugenoza, Klebseilla Pneumonia, Actinobacter MDR. Gram + bacteria: Staphylococcus aureus, Staphylococcus epidermides, micrococcus lutens, vancomycin resistance enterococcus, enterococcus faecalis, MRSA. Fungus isolates: Aspergillus, Rhizopus, Fuzarium, Yeast and Candida species And Mold.

\section{Results}

\subsection{Effects of Aveloz Latex on Mouse Breast Cancer Cells (EMT-6)}

EMT-6 cells $\left(1 \times 10^{4)}\right.$ taken during the logarithmic phase of growth were placed in each well of a 24 well plate in triplicate. Different dilutions of the aveloz were added to the wells, and the plates were incubated for 24 hours. The results obtained are summarized in (Table 2). There were complete lyses of the cell up to a 
dilution of 1:100. The viability was drastically reduced to a $22 \%$ at $1: 1000$ dilutions. At lower dilution the cell counts and viability were comparable to the control (fig. 1).

\begin{tabular}{|c|c|c|c|c|c|c|c|}
\hline \multirow[t]{2}{*}{ cancer cells } & \multicolumn{7}{|c|}{ Aveloz latex concentrations } \\
\hline & $10^{-1}$ & $10^{-2}$ & $10^{-3}$ & $10^{-4}$ & $10^{-5}$ & $10^{-6}$ & 0 (control) \\
\hline $\begin{array}{l}\text { No of viable } \\
\text { cells } / \mathrm{ml}\end{array}$ & 0 & 0 & $3.0 \times 10^{4}$ & $66 \times 10^{4}$ & $88.8 \times 10^{4}$ & $93.7 \times 10^{4}$ & $144.1 \times 10^{4}$ \\
\hline $\begin{array}{r}\text { No of dead } \\
\text { cells } / \mathrm{ml}\end{array}$ & $1 \times 10^{4}$ & $1 \times 10^{4}$ & $10.6 \times 10^{4}$ & $3.8 \times 10^{4}$ & $5 \times 10^{4}$ & $1.9 \times 10^{4}$ & $1.9 \times 10^{4}$ \\
\hline $\begin{array}{l}\text { Total no. of } \\
\text { cells } / \mathrm{ml}\end{array}$ & $1 \times 10^{4}$ & $1 \times 10^{4}$ & $13.6 \times 10^{4}$ & $69.8 \times 10^{4}$ & $93.8 \times 10^{4}$ & $95.6 \times 10^{4}$ & $146 \times 10^{4}$ \\
\hline$\%$ of viability & $0 \%$ & $0 \%$ & $22 \%$ & $94 \%$ & $95 \%$ & $98 \%$ & $99 \%$ \\
\hline
\end{tabular}

Table 2. Results of aveloz latex effects on mouse breast cancer cells.

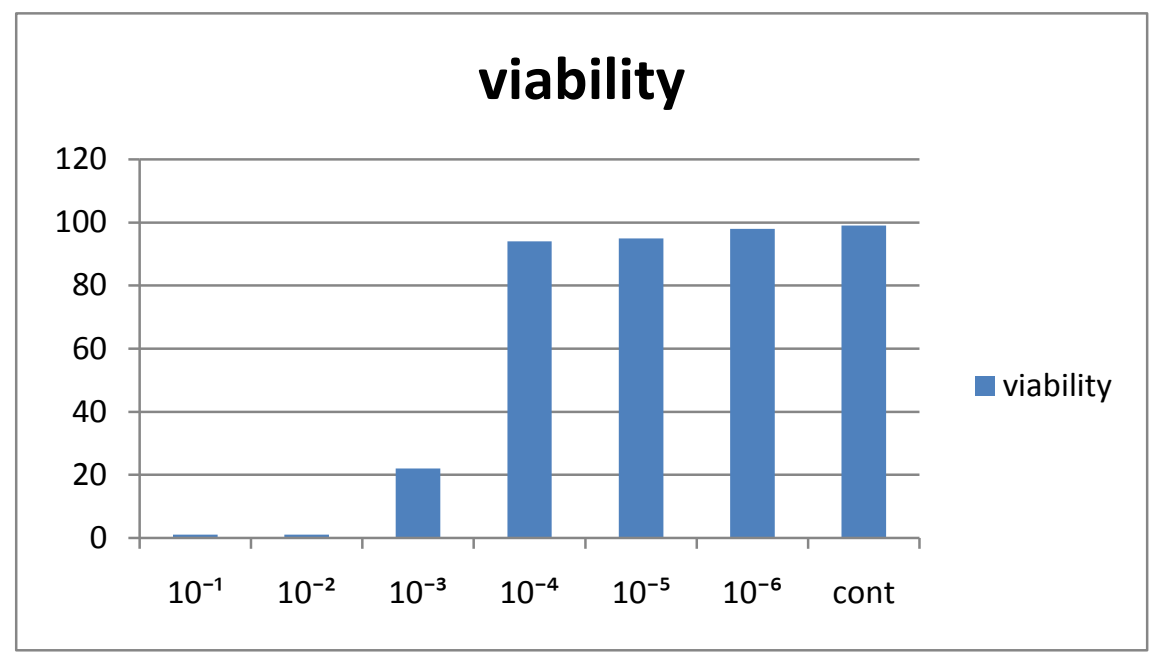

Fig.1 viability (\%) of cells at different dilutions $\left(10^{-1}-10^{-6}\right)$ of Aveloz, control without aveloz.

\subsection{Effects of Aveloz Latex Stem and Leaves Extracts on Bacteria}

Aveloz latex was tested on different strains of gram positive and gram negative bacteria. Different dilutions were added onto sterile filter papers placed on a lawn of bacteria spread on a Mueller Hinton agar following the recommendations of CLSI. The results obtained indicate that the aveloz latex had no antimicrobial activity. There was growth up to the edge of the filter paper discs with all dilutions used including a pure extract. Extracts from the stem and leaves demonstrated anti-bacterial activity for both gram positive and gram negative bacteria. Multidrug resistant non-typhoid Salmonella species and Pseudomonas aeruginosa were resistant to all dilutions including the original extract. The zones of inhibition are summarized in (Table 3).

\begin{tabular}{|c|c|c|c|c|c|c|c|c|c|c|c|c|}
\hline \multirow[t]{2}{*}{ Microbial species } & \multicolumn{4}{|c|}{ Aveloz latex concentrations } & \multicolumn{4}{|c|}{$\begin{array}{l}\text { stem extracts } \\
\text { concentrations }\end{array}$} & \multicolumn{4}{|c|}{$\begin{array}{l}\text { leaves extracts } \\
\text { concentrations }\end{array}$} \\
\hline & $\begin{array}{l}\text { Orig } \\
\text { conc }\end{array}$ & 1:1 & $1: 2$ & $1: 4$ & $\begin{array}{l}\text { Orig } \\
\text { conc }\end{array}$ & $1: 1$ & $1: 2$ & $1: 4$ & $\begin{array}{l}\text { Orig } \\
\text { conc }\end{array}$ & 1:1 & $1: 2$ & $1: 4$ \\
\hline Staphylococcus aureus & $\mathbf{0}$ & $\mathbf{0}$ & $\mathbf{0}$ & $\mathbf{0}$ & 24 & 16 & 12 & $\mathbf{0}$ & 14 & 12 & 6 & $\mathbf{0}$ \\
\hline Staphylococcus epidermidis & $\mathbf{0}$ & $\mathbf{0}$ & $\mathbf{0}$ & $\mathbf{0}$ & 32 & 28 & 20 & $\mathbf{0}$ & 32 & 28 & 20 & $\mathbf{0}$ \\
\hline Micrococcus lutens & $\mathbf{0}$ & $\mathbf{0}$ & $\mathbf{0}$ & $\mathbf{0}$ & 28 & 20 & 14 & 12 & 28 & 22 & 10 & $\mathbf{0}$ \\
\hline MRSA & $\mathbf{0}$ & $\mathbf{0}$ & $\mathbf{0}$ & $\mathbf{0}$ & 17 & 14 & $\mathbf{0}$ & $\mathbf{0}$ & 24 & 18 & 14 & $\mathbf{0}$ \\
\hline Enterococcus Faecalis & $\mathbf{0}$ & $\mathbf{0}$ & $\mathbf{0}$ & $\mathbf{0}$ & 14 & 14 & $\mathbf{0}$ & $\mathbf{0}$ & 24 & 18 & 10 & $\mathbf{0}$ \\
\hline $\begin{array}{l}\text { Vancomycin resistance } \\
\text { enterococcus }\end{array}$ & $\mathbf{0}$ & $\mathbf{0}$ & $\mathbf{0}$ & $\mathbf{0}$ & 22 & 14 & 6 & $\mathbf{0}$ & 24 & 20 & 14 & $\mathbf{0}$ \\
\hline Proteus mirabilis & $\mathbf{0}$ & $\mathbf{0}$ & $\mathbf{0}$ & $\mathbf{0}$ & 20 & 16 & 14 & $\mathbf{0}$ & 20 & 16 & 14 & $\mathbf{0}$ \\
\hline Shigella sonnei & $\mathbf{0}$ & $\mathbf{0}$ & $\mathbf{0}$ & $\mathbf{0}$ & 22 & $\mathbf{0}$ & $\mathbf{0}$ & $\mathbf{0}$ & $\mathbf{0}$ & $\mathbf{0}$ & $\mathbf{0}$ & $\mathbf{0}$ \\
\hline Shigella flexneri & $\mathbf{0}$ & $\mathbf{0}$ & $\mathbf{0}$ & $\mathbf{0}$ & 30 & 28 & 10 & $\mathbf{0}$ & 30 & 20 & 10 & $\mathbf{0}$ \\
\hline Salmonella & $\mathbf{0}$ & $\mathbf{0}$ & $\mathbf{0}$ & $\mathbf{0}$ & $\mathbf{0}$ & $\mathbf{0}$ & $\mathbf{0}$ & $\mathbf{0}$ & $\mathbf{0}$ & $\mathbf{0}$ & $\mathbf{0}$ & $\mathbf{0}$ \\
\hline Acinitobacter baumanii & $\mathbf{0}$ & $\mathbf{0}$ & $\mathbf{0}$ & $\mathbf{0}$ & 20 & 18 & 14 & $\mathbf{0}$ & 24 & 20 & 8 & $\mathbf{0}$ \\
\hline E. coli & $\mathbf{0}$ & $\mathbf{0}$ & $\mathbf{0}$ & $\mathbf{0}$ & 30 & 20 & 16 & $\mathbf{0}$ & 30 & 20 & 10 & $\mathbf{0}$ \\
\hline Pseudomonas aeruginosa & $\mathbf{0}$ & $\mathbf{0}$ & $\mathbf{0}$ & $\mathbf{0}$ & 24 & 20 & 6 & $\mathbf{0}$ & 24 & 20 & 6 & $\mathbf{0}$ \\
\hline Pseudomonas aeruginosa & $\mathbf{0}$ & $\mathbf{0}$ & $\mathbf{0}$ & $\mathbf{0}$ & 6 & $\mathbf{0}$ & $\mathbf{0}$ & $\mathbf{0}$ & 8 & $\mathbf{0}$ & $\mathbf{0}$ & $\mathbf{0}$ \\
\hline Klebseilla pneumonia & $\mathbf{0}$ & $\mathbf{0}$ & $\mathbf{0}$ & $\mathbf{0}$ & 20 & 14 & $\mathbf{0}$ & $\mathbf{0}$ & 24 & 20 & 14 & $\mathbf{0}$ \\
\hline
\end{tabular}

Table 3. Zone diameter of inhibition in $\mathrm{mm}$ of latex, and stem and leaves extracts on Bacteria. 


\subsection{Effects of Aveloz Latex Stem and Leave Extracts on Fungus Isolates}

Although aveloz latex had no antibacterial activity, it showed antifungal activity at high concentration against Aspergillus, Mucor, Rhizopus and Candida spp. The effects obtained were either due to the pure extract or a 1:10 dilution. The results are shown in (Table 4). The extracts obtained from the stem and leaves had limited or no activity against fungi, the results is summarized in Table 6 below.

Table 4. Diameter of inhibition zones in $\mathrm{mm}$, caused by aveloz materials on fungi.

\begin{tabular}{|c|c|c|c|c|c|c|c|c|c|c|c|c|c|}
\hline & $\begin{array}{l}\text { Aveloz } \\
\text { concent }\end{array}$ & $\begin{array}{l}\text { itex } \\
\text { ation }\end{array}$ & & & & $\begin{array}{l}\text { Aveloz } \\
\text { concen }\end{array}$ & $\begin{array}{l}\text { em e } \\
\text { ation }\end{array}$ & 2 & & $\begin{array}{l}\text { Aveloz } \\
\text { concen }\end{array}$ & $\begin{array}{l}\text { ave } \\
\text { atio }\end{array}$ & $x \operatorname{xtr}$ & \\
\hline & Origin & $\begin{array}{l}1: 1 \\
0\end{array}$ & $\begin{array}{l}1: 2 \\
0\end{array}$ & $\begin{array}{l}1: 4 \\
0\end{array}$ & $\begin{array}{l}1: 8 \\
0\end{array}$ & Origin & 1: 1 & $\begin{array}{l}\text { 1: } \\
2\end{array}$ & $\begin{array}{l}1: \\
4\end{array}$ & Origin & $\begin{array}{l}1: \\
1\end{array}$ & $\begin{array}{l}1: \\
2\end{array}$ & $1: 4$ \\
\hline $\begin{array}{l}\text { Aspergill } \\
\text { us }\end{array}$ & 28 & 20 & 0 & 0 & 0 & 6 & 4 & 0 & 0 & 6 & 6 & 0 & 0 \\
\hline Mucax & 20 & 16 & 0 & 0 & 0 & 16 & 10 & 0 & 0 & 10 & 6 & 0 & 0 \\
\hline Fuzanu & 0 & 0 & 0 & 0 & 0 & 6 & 0 & 0 & 0 & 8 & 5 & 0 & 0 \\
\hline Yeast & 0 & 0 & 0 & 0 & 0 & 0 & 0 & 0 & 0 & 0 & 0 & 0 & 0 \\
\hline$R_{\text {SRQpus }}$ & 30 & 26 & 20 & 16 & 0 & 6 & 0 & 0 & 0 & 4 & 0 & 0 & 0 \\
\hline Candida & 16 & 10 & 6 & 0 & 0 & 17 & 8 & 0 & 0 & 14 & 8 & 6 & 0 \\
\hline yeast & 20 & 0 & 0 & 0 & 0 & 0 & 0 & 0 & 0 & \begin{tabular}{|l|}
0 \\
\end{tabular} & 0 & 0 & 0 \\
\hline Mold & 0 & 0 & 0 & 0 & 0 & 0 & 0 & 0 & 0 & 0 & 0 & 0 & 0 \\
\hline Mold & 0 & 0 & 0 & 0 & 0 & 6 & 6 & 0 & 0 & 6 & 0 & 0 & 0 \\
\hline
\end{tabular}

\section{Discussion}

Our results indicated that aveloz latex suppressed and prevented the growth of mouse breast cancer cells. At high concentration, it caused cell lyses and drastically reduced cell viability at lower concentration. A study speculated that the mechanism of the antitumor activity of euphorbia tirucalli may be related to the regulation of granulocyte and macrophage production and expression of functional activities (4). Another study revealed that latex has induced suppressed activity on CD4+ and CD8+ T-cells, inhibited interleukin-2 and gama- interferone production and affected immunomodulation (5). It was finding that latex taken internally caused reduction in lymphocytes number (6). Research conducted on tumor bearing mice with myelosuppression and increased number of spleen CFU-GM, latex reduced these cells (spleen colony formation), reduced prostaglandin E2 that is normally elevated in tumor bearing mice and caused reduction in tumor growth in the peritoneal cavity. This indicates the presence of antitumor activity of euphorbia tirucalli (4). A study on latex revealed that it enhanced the growth of EBV which led to Burkitts lymphoma (7). Literature search did not reveal many articles related to the antitumor activity of this herb. Most of the information provided in literature lacked scientific basis. No articles were detected in literature dealing with the effects of aveloz on breast cancer cells tested in this work or any other cell lines. The antibacterial and antifungal properties of latex were not investigated in literature. The only article found indicated that extracts from the stem and leaves of Euphorbia tirucalli have anti herbes simplex virus -2 effects (8). As indicated in the results obtained in this project, the aveloz latex gave some antifungal activity. The numbers of the fungal isolates tested were not enough to draw major conclusion. Extracts from the leaves and stems of this herb demonstrated antibacterial activity. Most of the gram positive and gram negative bacterial isolates were susceptible to this extract to a reasonable dilution (1:4). Exceptions were seen in multidrug resistant A. baumanii, Pseudomonas aeruginosa, and Salmonella and Shigella species. The drawbacks of the antimicrobial effects of this herb are the unavailability of literature discussing this issue. Therefore we are unable to compare our results with others.

\section{Conclusion}

Aveloz may be a promised medical plant to produce medicinal preparations for treatment different bacterial, fungal and tumor diseases, so the results of this research give informational supports to work on this plant by pharmaceutical companies' researches.

\section{Conflict of Interest Statement}

The authors declare that there is no conflict of interest with any financial organization or corporation or individual that can inappropriately influence this work. 


\section{References}

[1]. Ang-Lee MK, Moss J, Yuan CS. Herbal medicines and perioperative care. JAMA. 286(20:208-216

[2]. Cataluña, P, et al. "The traditional use of the latex from Euphorbia tirucalli Linnaeus (Euphorbiaceae) in the treatment of cancer in South Brazil." ISHS Acta Horticulture 501: II WOCMAP Congress Medicinal and Aromatic Plants, Part 2: Pharmacognosy, Pharmacology, Phytomedicine, Toxicology.'

[3]. Duke, J. Euphorbia tirucalli L. Handbook of Energy Crops. Unpublished. 1983. Available through Purdue University Center for New Crops \& Plants Products.

[4]. Valadares MC, et al. euphorbia tirucalli L. modulates myelopoiesis and enhances the resistance of tumor -bearing mice. int. Immunopharmacol, 2006 Feb; 2: 294-9.

[5]. Bani S, et al. anti- arthritic activity of a biopolymeric fraction from Euphorbia tirucalli. J Ethnopharmacol. 2007 Mar 1; 110(1): 928.

[6]. Mac Neil, A, et al. Activation of the Epstein-Barr virus lytic cycle by the latex of the plant Euphorbia tirucalli.Br J Cancer 2003; 88:1566- 69.

[7]. Yoshikazu Yamamoto 1, Ryuzo Mizuguchi 1, and Yasuyuki Yamada 2 Technical Center, Nippon Paint Co. Ltd., 19-17, Ikeda Nakamachi, Neyagawa, Osaka 572, Japan. 2 Department of Agricultural Chemistry, Kyoto University, Kyoto 606, Japan Received April 3, 1981.

[8]. Betancur LA, et al. Cytotoxic and antiviral activities of Colombian medicinal plant extracts of the Euphorbia genus. Mem Inst Oswaldo Cruz, 2002 Jun;97(4):541-6.

[9]. Gary A. Thibodeau, Kevin T. Patton. Female reproductive system, Anatomy and Physiology, second edition 1993 book.

[10]. Freedman, et al. cancer incidence in four member countries of the Middle East cancer consortium compared with US SEER. NIH PUB, 2006.

[11]. Mayo clinic: mayo foundation for medical education and research. Breast cancer chemoprevention, medicines that reduce breast cancer risk,(Wo000092), Jan. 21, 2009.

[12]. Inas Elattar. Breast cancer: magnitude of problem, national cancer institute - Cairo University, Egypt society of surgical oncology conference, 2005.

[13]. Breastcancer.org 7 East Lancaster Avenue, 3rd Floor Ardmore, PA 19003 November 26, 2008.

[14]. The general recorder the Jordanian organization for the cancer, IARC, 2004; 8: 33.

[15]. Yael Rockoff, et al. Coping with Breast Cancer among Palestinian and Israeli Women Project COPE, Final Report, Phase A, 2000 2003

[16]. Gonzales, et al. overview of resistance to systemic therapy in patients with breast cancer. Department of Breast Medical Oncology, Adv Exp Med Biol. 2007; 608:1-22.

[17]. University of Maryland Medical Center (UMMC). Herbal medicine, 22 S. Greene Street, Baltimore, MD 21201. TDD2008: 401.328.9600 or 1.800 .492 .5538

[18]. Miller S, et al. Botanicals used in complementary and alternative medicine treatment of cancer: clinical science and future perspectives. Expert Opin Investig Drugs 2008; 9: 1353-64.

[19]. Chen Z, et al. the use of complementary and alternative medicine among Chinese women with breast cancer, Alternative complement med, 2008; 8:1049-55

[20]. Shumay DM, et al. why some cancer patients choose complementary and alternative medicine instead conventional treatment. J. Fam Pract. 2001; 12: 1067- 70.

[21]. Ucan $\mathrm{O}$, et al. herbal treatment in Turkish, The use of complementary therapies in cancer patients: a questionnaire- based descriptive survey from southeastern Turkey, Am J Clin Oncol 2008; 31(6): 589-94

[22]. Liu S, et al. Effects of Ru'ai Shuhou Recipe on 5-year recurrence rate after mastectomy in breast cancer Zhong Xi Yi Jie He Xue Bao, 2008; 10:1000-1004

[23]. Silva, ACP, et al. Toxicological screening of Euphorbia tirucalli L.: Developmental toxicity studies in rats. Ethnopharmacol 2007; 110:154-159.

[24]. Desai AG, et al. Department of Environmental Health Sciences, Mailman School of Public Health, drug chemoprevention, Curr. Drug Metab. 2008 Sep; 9(7):581-9.

[25]. Morant R, et al. why do cancer patients use alternative medicine. Abteilung fur Onkologie 1991 Jul; 121:1029- 34

[26]. Jigna Parekh, et al. Efficacy of Aqueous and Methanol Extracts of Some Medicinal Plants for Potential Antibacterial Activity. Turk J Biol 2005; 29:203- 210.

[27]. Maregesi S, et al. Screening of Tanzanian Medicinal Plants against Plasmodium falciparum and Human Immunodeficiency Virus. Planta Med 2009 Aug 3. 